\title{
Agro-Biodiversity Spatial Assessment and Genetic Reserve Delineation for the Pollino National Park (Italy)
}

\author{
Giovanni Figliuolo1, Domenico Cerbino² \\ ${ }^{1}$ Dipartimento delle Culture Europee e del Mediterraneo: Architettura, Ambiente, Patrimoni Culturali, \\ Università degli Studi della Basilicata, Matera, Italy \\ ${ }^{2}$ Agenzia Lucana di Sviluppo e Innovazione in Agricoltura, Rotonda, Italy \\ Email: giovanni.figliuolo@unibas.it
}

Received 4 March 2014; revised 8 April 2014; accepted 23 April 2014

Copyright (C) 2014 by authors and Scientific Research Publishing Inc.

This work is licensed under the Creative Commons Attribution International License (CC BY).

http://creativecommons.org/licenses/by/4.0/

(c) (i) Open Access

\begin{abstract}
Ancient fruit trees, grape vines, traditional crop and garden cultivars have been inventoried in Pollino National Park by adopting a spatial sampling grid which covers 23 different municipalities $\left(\sim 1500 \mathrm{Km}^{2}\right)$ and 190 surveyed sites. Each site is a circle with a visible radius of $200-250 \mathrm{~m}$. The spatial analysis of the diversity of plant genetic resources has been conducted with pre-fixed landscape units (size: $4 \mathrm{Km} \times 4 \mathrm{Km}$ ). Overall, 49 different woody long cycle (455 ancient cultivars) and 53 short cycle species (102 ancient cultivars) have been scored. Long cycle species exhibit higher cultivar richness than short cycle species. The analysis has recognized that pre-Columbian indigenous cultivars had not been displaced by the American species introduced after the $16^{\text {th }}$ century. In addition, it is confirmed that small-scale poly-production, under conditions of spatial niche variation, is associated to high species and cultivar richness. The mapped realized niche, for both pre- and post-Columbian genetic resources, includes the actual genetic reserve suitable for in situ conservation of plant agro-biodiversity. Agro-biodiversity models, drivers of genetic erosion, and realistic responses to genetic erosion are outlined.
\end{abstract}

\section{Keywords}

Genetic Reserve, Genetic Resource, Realized Niche, Richness, Spatial Analysis

\section{Introduction}

Integrating spatial analysis methods [1] [2] and team-work into community based approaches [3] is basic for implementing the in situ conservation of plant genetic resources. Spatial agri-biodiversity monitoring would 
positively affect forward-looking anticipatory management plans for landscapes of the European protected areas bearing high richness of species and cultivars within species. Overall, $\sim 338,000 \mathrm{Km}^{2}$ of the European agricultural agro-ecosystems (except humid areas, prairies and forested land-cover) are within the boundaries of the protected areas. This type of overlapping accounts for $\sim 97,000 \mathrm{Km}^{2}$ and $\sim 45,000 \mathrm{Km}^{2}$ in North America and Oceania respectively. Italy includes about $\sim 60,000 \mathrm{Km}^{2}$ of high natural value agro-ecosystems [4] [5]. Thus the European landscape context is consistent with the principle of managing protected areas taking into account both domesticated and wild genetic resources.

The monitoring and reviewing the state of biodiversity makes it possible to achieve the goals stated at global [6] [7] and regional level [8] [9]. Biodiversity mapping is the approach aimed at maintaining ancient crop cultivars within their traditional cropping systems by local farmers (on-farm conservation) [3] [10] [11]. Landscape maps of cultivars and species richness are necessary to identify priority conservation areas. Some of these areas are in urgent need of conservation action, while others are not [12]. Knowing precisely both the conservation site of the genetic material and the driving forces which must be controlled is the pre-condition to halt or reduce the extinction risk of ancient cultivars [13]. Efficient biodiversity management may positively affect ecology, economy and welfare of small-holder farmers, gardeners and non-farmers amateurs.

The breeder or the gene-bank manager approaches to ex-situ conservation in the past focused on the search of desired genes or on representative population seed samples respectively. The outcome was that long living species, such as fruit trees or grape vines, have been often excluded from the list of surveyed species, although their farming, since ancient times, indicates high technical skill and ability to integrate the trees into wider ecosystem equilibriums [14].

Pollino National Park, located in the Mediterranean Region (south Italy), is the largest (192,565 Ha) Italian protected area. The territory including each park municipality rises to 294.630 Ha [15]. Geomorphologic variables and soil type, display uneven variation over short distances and, climate is more (north, north-west faced slopes) or less (south, south-east faced slopes) humid [16]. The array of woods, primary and secondary prairies, fruit trees and cereal cultivations, garden vegetables farmed along the rivers and close to springs, can be depicted as a semi-natural mosaic of habitats. The landscape as a result of its parts is the integration of wood (silva), prairie bordering wood margins (saltus), cultivated field (ager), traditional garden rings (hortus) surrounding urban demes. The above set of geographic elementary units reflects the traditional Italian landscape pattern [17]. Each ecotonal belt between saltus and silva captures semi-wild pear and apple monumental trees. The blunt connection between wild, semi-wild and anthropological landscape units is a typical feature of the Pollino National Park [18].

Phytonymes (synonymy and homonymy) reflect anthropologic and linguistic diversities as well as the historical pattern of human migrations [19]. A link between cultivar introductions and human migrations has been noticed: From the first Indo-European waves (neolitic) [20], Hellenics ( 720-420 B.C.), Italics (Lucani, Bruzii, Sanniti and Romans $\sim 600-265$ B.C. and later on), Jews ( 300-1500), Greek-Byzantines, Longobards ( 500$1200)$, Saracens ( 800-1300), Nordmans ( 1000-1266), Albanians, Dalmatians, Bulgarians ( 1448-1647), Spanish, to periods of French influence (1300 to the modern age) [19]; and, recently, the local people coming back from the African colonies (1914-1943).

Perceptually distinctive traits (phenotypic and use traits) [21] enable each traditional cultivar to be distinguished and named. The tree bearing fruit, as elsewhere detected [22], is often landmark of the family life-cycle: The birth of a child, the inheritance from relatives, the field boundary or the owner's social rank. All these features allow in situ conservation of the ancient cultivars. Analyzing spatial agri-biodiversity patterns in one of the most inland Italian regions would represent the first step toward effective genetic resources conservation for agriculture, food and tourism.

This paper reports the spatial analysis of the ancient cultivars of Pollino National Park in situ regenerated. The analysis focuses on: 1) Species richness, cultivar richness, cultivar vulnerability; 2) Spatial pattern of biodiversity; 3) Historical displacement effects; 4) Genetic reserve delineation for genetic resource management and planning.

\section{Method}

\subsection{Sampling Design and Data Collecting}

We define "ancient cultivar" a botanical entity (landrace, cultivar or biotype) reproduced and maintained within 
a given agro-ecological context since historical time or, at least, over the last 50 years.

Ancient cultivars of long living fruit tree, garden and herbaceous crop cultivars have been surveyed from 2009 to 2011 in the target area ( $1500 \mathrm{~km}^{2}$ and 23 different municipalities) of Pollino National Park. The area comprises Mercure, Frida, Serrapotamo, Sinni (upper and lower valley), and Sarmento catchments basins (Figure 1). Monitoring and sampling strategy was according to the pilot project for the Val D'Agri [12] [23]. Sampling sites were 119 geo-referenced circles, each one with a radius of about $200-250 \mathrm{~m}$ (the eye score distance) (Figure 1). Each site-described by its altitude, location name, soil exposition, soil type, structure, colour, land owner(s) age, name and satellite coordinates-is included in wider landscape units (silva, saltus, ager and hortus). The land of each sampling unit belongs to one or more owners or, in some instances (i.e. silva and saltus), is public domain land. The selection of each sampling unit is based either on the visible biological richness or on representative and accessible landscapes. The local network of custodian farmers enhanced communication among persons and improved the understanding of plant diversity.

For cultivar distinction, priority was given to traits (e.g. fruit shape, colour, period of harvest) providing perceptual distinctiveness [21]. Perceptual traits are sufficient to recognize and name each cultivar based either on perceived phenotypes or type of use. Digital images, fruits, seeds and plant specimens were also collected. To target different earliness categories, repeated surveys were carried out. Key questions were asked in the survey to assess cultivar name(s), plant use, and time since their first introduction, persons involved and harvest period. Each cultivar was in situ identified with photo of the whole plant, fruits and leaves. The $1^{\text {st }}$ phase of the eco-geographic survey focused on perennial species, the $2^{\text {nd }}$ phase on short cycle species. Database cross-validation allowed the attribution of a unique cultivar name after correcting either for the redundancy due to synonyms or the lumping due to homonyms.

\subsection{Diversity Analysis}

The merge of two different databases $\left(1^{\text {st }}+2^{\text {nd }}\right.$ survey), separately used to report the fieldwork [18] [24], allowed a complete spatial diversity analysis. After database cross-validation diversity indices (Richness, Marga-

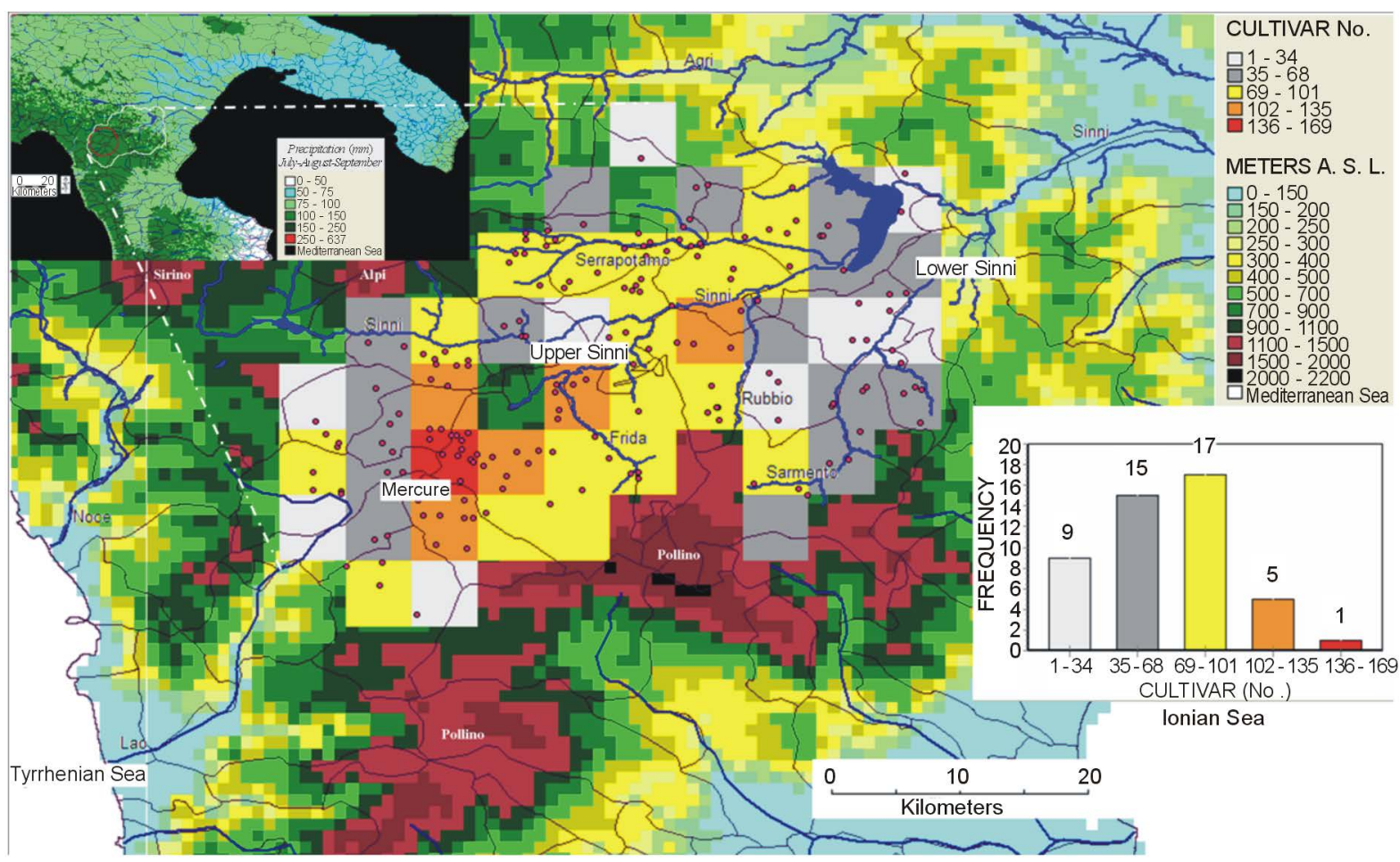

Figure 1. Cultivar No./16 Km² landscape cell surface mapped in 23 municipalities of Pollino National Park by adopting a sampling grid of 119 sites $(\bullet)$. Top left map indicates spatial distribution of the average precipitation in the third (warmest and driest) trimester. Red area indicates the richest niche; the white boundary delimits the total surveyed rural area ( 1500 $\mathrm{km}^{2}$ ). Bottom-right chart indicates cell surface frequencies for each cultivar richness class. 
lef, Menhinick, Shannon, Simpson and Briliouin) were computed for each $16 \mathrm{Km}^{2}$ elementary grid cell and for the whole landscape [25] (Figure 1). Biodiversity landscape maps were generated with rasters displaying diversity values for each elementary cell. The "circular neighborhood" option, adopted a "grid richness analysis" with a 30 arc sec cell size and circular neighborhood of 0.1 degree.

The "reserve selection", produced a raster displaying a richness analysis of the priority cells for conservation. The whole set of selected cells, using Rebelo's complementary algorithm [26], is assumed sufficient to conserve all cultivars with the minimum of repetitiveness by including the unique observations [25].

The ecologic distribution of each cultivar was categorized according to Brown [27] as: 1) Common (locally) and widely distributed (CWD); 2) Common and locally distributed (CLD); 3) Rare (locally) and widely distributed (RWD); 4) Rare and locally distributed (RLD).

Gene-pool has been partitioned first based on the species biological form (i.e. long vs short cycle) and, second on the basic historical groups (pre-Columbian vs Columbian). Columbian cultivars are those introduced in Europe after the $15^{\text {th }}$ century from Centre and South America.

Climatic, phithoclimatic [28] [16] and geo-pedologic [29] diversity has been assessed with the geographic information system (GIS). Average bio-climatic variables [30] have been estimated from the hourly records (time-period: 2000-2011) at the weather station on the margin of Mercure valley using the statistical analysis system software (SAS) [31].

\section{Results}

\subsection{Overall Biodiversity State}

Forty nine (49) woody long cycle fruit bearing species (comprising 455 different traditional cultivars) and 53 herbaceous short cycle species (comprising 102 traditional cultivars) were scored through 119 sampling sites (Table 1, Figure 1). Species to cultivar ratio is higher among long cycle than short cycle species (9.2 vs. 2.4 respectively).

Cultivar number included within the average landscape grid cell unit ranges from 69 to 101 and, 169 different cultivars (the maximum richness) are captured by the unique hot-spot cell (Figure 1). Cultivar richness distribution per geographic cell is maximum (60 - 110 different cultivars) along a landscape corridor from Mercure to Serrapotamo area (Figure 1). Overall, the cultivar category RLD is the most common, followed by the categories CLD, RWD and CWD.

The relationship "species richness to cultivar richness”, per grid cell unit (Table 2), is straighter for short cycle than for long cycle genetic resources.

Table 1. Overall diversity indices $\left(^{*}=\right.$ for cultivars).

\begin{tabular}{cccc}
\hline $\begin{array}{c}\text { Diversity } \\
\text { index }\end{array}$ & Woody long cycle & Herbaceous short cycle & All \\
\hline Species No. & 49 & 53 & 102 \\
Cultivar No. & 455 & 130 & 585 \\
Species:Cultivar & $1: 9.2$ & $1: 2.4$ & $1: 5.7$ \\
Margalef* $^{*}$ & 55.34 & 18.04 & 68.68 \\
Menhinick $^{*}$ & 7.52 & 3.65 & 8.33 \\
Shannon $^{*}$ & 5.09 & 4.14 & 5.42 \\
Simpson $^{*}$ & 0.99 & 0.97 & 0.99 \\
Brillouin $^{*}$ & 4.91 & 3.96 & 5.23 \\
\hline
\end{tabular}

Table 2. Significant $(\mathrm{P}<0.01)$ linear relationships between richness for different plant categories per each $16 \mathrm{Km}^{2}$ cell unit.

\begin{tabular}{ccc}
\hline Linear Regression & Slope & $\mathbf{R}^{2}$ \\
\hline L.c. cultivar No. vs. L.c. species No. & 0.31 & 0.88 \\
S.c. cultivar No. vs. S.c. species No. & 0.55 & 0.94 \\
L.c. cultivar No. vs. S.c. cultivar No. & 0.36 & 0.76 \\
Columbian cultivar No. vs. pre-columbian cultivar No. & 0.41 & 0.76 \\
L.c. $=$ Long cycle; S.c. $=$ Short cycle & & \\
\hline
\end{tabular}


The logarithmic relationship between species and cultivar richness (Figure 2) is that above the threshold of 15 - 20 species per spatial cell unit, the marginal increase in cultivar No. is high because of the effect of species with high cultivar richness (i.e. pear, apple and grape vine).

The richness increase of fruit tree cultivars is linearly correlated $(r=0.36 ; P<0.01)$ with the number of herbaceous traditional cultivars. It follows that areas rich in woody species are also rich in herbaceous cultivars (Table 2). Columbian cultivars (those introduced after $15^{\text {th }}$ century) augmented the biological richness within the agrological niches previously occupied by the pre-Columbian ones, without significant displacement effects $(r=0.41 ; P<0.01)$ (Table 2). The historical biodiversity trend is consistent with the rising biological richness.

The genetic reserve (see ch. 3.4.) indicates as Mercure area (red cell) alone captures 169 different ancient cultivars, while each green cell indicates the number of new cultivars (from 14 to 66) not present in any of the previously selected cells.

\subsection{Long Cycle Species}

Pyrus communis (pear), Malus domestica (apple) and Ficus carica (fig) are the top-most dominant species (Figure 3). Pear is composed of 144 biotypes; most of them (Maiatica, Limone, Gentile, Campanella, Mirizzosa, etc.) categorized as RWD were probably widely used in the past. Others are CWD or CLD (Acquarola, Balcone, Bella, Spadona, etc.) because of their range of adaptation and persisting preference by the domestic custodians. Biotypes RLD are represented by one or few individuals in one or two sampling sites, and thus very vulnerable. Each individual is often represented by a monumental tree (10 - $15 \mathrm{~m}$ tall).

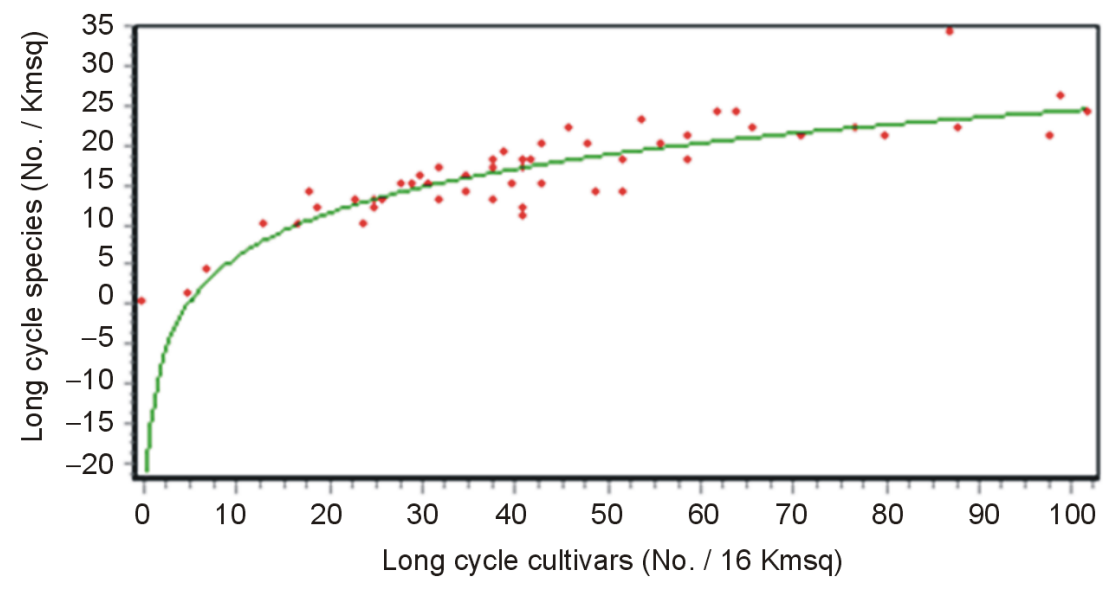

Figure 2. Log. regression between long cycle woody species No. and long cycle woody cultivar No. per each $16 \mathrm{Km}^{2}$ cell unit $(P<0.01)$.

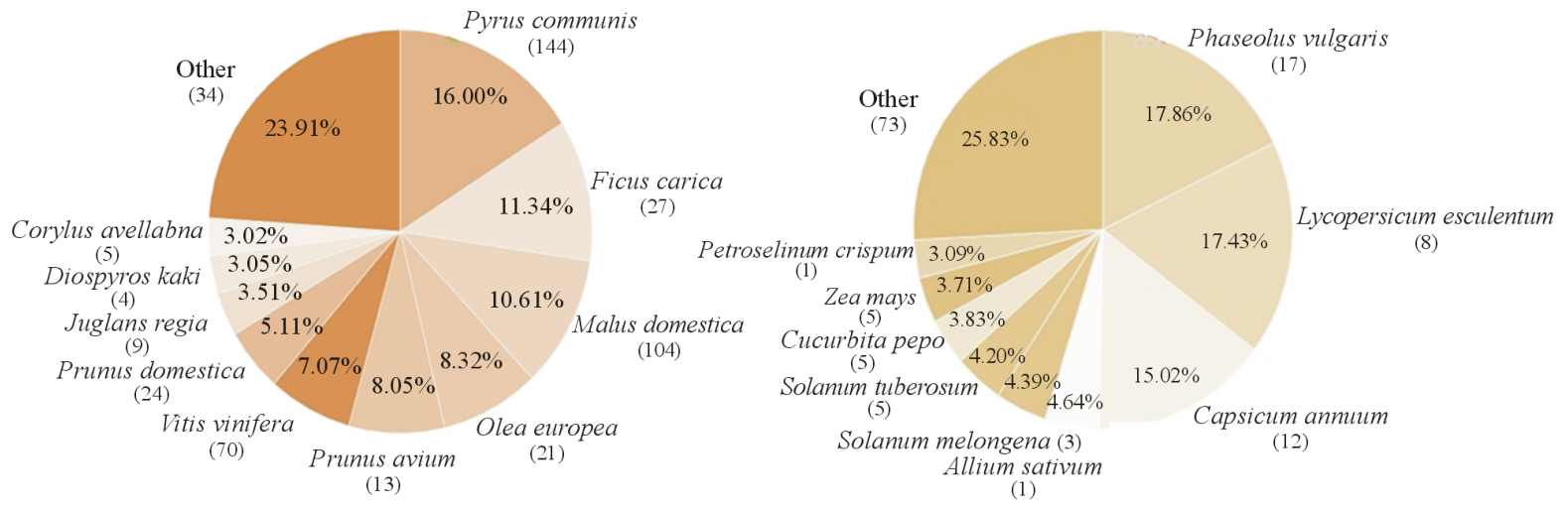

Figure 3. Abundance (\% of occurrence) vs. cultivar richness (in parenthesis) either for fruit tree (left) or for short cycle species (right). Category "other" captures from 29 (fruit trees) to 44 (short cycle) species. Correlation between species abundance and cultivar richness within species is $r=0.80(P<0.05)$. 
Broadly two main different pear sub-groups can be distinguished based on fruit shape, texture and colour. The first one (Trentatrejuonze, Strangoglie, Spadone, Acquarole, Cioccolate, Cognute, Spina, etc.) is linked to Pyrus pyraster and Pyrus amygdaliformis (wild sympatric progenitors). The second (Codilonghe, Giovanne, Rosse, etc.) probably share additional ancestry with Pyrus caucasica, a wild species endemic to the Asiatic centre of origin. Inter-specific gene-flow between pear cultivars and wild specimens, as well as between apple cultivars and the wild Malus sylvestris is demonstrated by the $\mathrm{F}_{1}$ and backcrossed generations frequently found in abandoned fields. Several pear cultivars (e.g. Zilariello, Praino, Agresta) are very close to the wild phenotype.

Apple comprises 68 different biotypes differentiated by earliness, fruit shape, size and colour. The spatial pattern of apple is similar to that of pear. The most widely distributed cultivars (Annurca, Rimoncella, Limoncella piatta, Renetta, Fano, Sirica and S. Giovanni) are appreciated by the local owners. Rimoncella (Limoncella campana) and Annurca performed as the most important cultivars until 1950. Each is composed of different biotypes. Some cultivars (e.g. Limone and Olio) are locally rare and widely distributed (RWD). Cultivars RLD (e.g. Cerrata, Schiacciata) are at high risk of extinction.

The most important wild progenitor of apple cultivars is M. sylvestris; nonetheless, red coloured apples (Annurca, Sirica, etc.) could share as ancestor Malus sieversii, a red apple endemic to Kazakhstan. Fig, Olea aeuropea (olive), Prunus avium (cherry), Vitis vinifera (grape), Prunus domestica (plum), and Juglans regia (walnut) are each one abundant and rich of traditional cultivars. Among figs, Gattarolo, Troiano, Dottato and Nero cultivars are RWD, while Pilosello verde and Pilosello nero are RLD.

Olive maximum richness was scored over the eastern side of the territory with the following cultivars: Rosana, Racioppella, Ogliastro, Ulivella, Fasulo, Ogliarola, Pendolino, Faresana and Dolce di Chiaromonte. A wide range of cherry cultivars, from the earliest (May) to the late types (August) are CWD.

Vitis vinifera var. sativa plus Riparia, Rupestris, Berlandieri (grape vine) includes 70 different cultivars. Common feature of the old vineyards is their composition: each vineyard is a mixture of different old cultivars. Pre-dating the introduction (second half of the $19^{\text {th }}$ century) of the north American vines are the following cultivars: Aglianico, Asprina, Colatamburro, Castiglione, Ciliegiolo, Gaglioppo, Guarnaccia, Guarnaccino, Lacrima, different Malvasia and Moscato biotypes, Monduonico, Stronzoporcino, Verdara bianca and, probably, Produttore nero antico. Grape vine used as fruit are Capezzola bianca di vacca, Minna di vacca, Iuvedda and Malvarosa.

After 1850 till 1900 French types (Francese bianca and nera) and Produttori (resistant to pathogen fungi) were introduced. The pest philloxera in 1879 irrupted in Europe. Its biological control was achieved after introducing the American resistant rootstocks Riparia, Rupestris, Berlandieri species and their hybrids.

Plum is represented by the following main cultivars: Cascavelle, Grumelle, Passolaspagna (damson type), and different types of Verdone (Quinn Giovanna type). Endemic to south Italy is Prunus cocomilia: A wild yellow plum growing on the edge of beech forest. $P$. cocomilia specimens have been found as new introductions in the rural field.

Remnant monumental trees of Morus alba and Morus nigra, first introduced by the Greek-Byzantines, are witness of the past silk industry.

Sorbus torminalis (wild service tree), Sorbus aria (white beam) and Sorbus aucuparia (mountain ash) have been also inventoried.

New introductions, mainly ornamental cultivars (Malus pumila, Chaenomeles japonica), were recorded (although not ancient) to indicate that for long cycle plants the process of introduction is in progress.

\subsection{Short Cycle Species}

Abundant (3\% - 18\% of occurrence) and rich of cultivars (90 different cultivars), are six Columbian species: Phaseolus vulgaris (common bean), Lycopersicon aesculentum (tomato), Capsicum annuum (sweet and hot pepper), Solanum tuberosum (potato), Zea mays (maize), and Cucurbita pepo (Figure 3). Abundant are also Allium sativum, Solanum melongena, and Petroselinum crispum. Common bean is characterized by 17 distinct traditional cultivars.The open field bean cultivars with determinate growth are almost all extinct. Sweet and hot pepper are widely distributed with their maximum richness (8 - 10 different cultivars) at Senise and Mercure areas. Among them the most appreciated is pepper (Senise rosso). In the same area are grown four traditional eggplant cultivars and two Solanum aethiopicum (African red eggplant) biotypes probably introduced by Italian colonizers in the early $20^{\text {th }}$ century. Four traditional potato cultivars have been found. Either the red or white types are farmed at about $1000 \mathrm{~m}$ of altitude (Francavilla and Terranova). 
Cucurbita maxima, C. pepo and C. moschata are very common in fresh and deep soils of gardens fertilized with organic manure. The "Viggianello type" of C. maxima RLD is used to produce dried ring slices. C. pepo includes types with either indeterminate (typical of the fresh gardens) or determinate growth. At least four different cultivars of C. moschata have been identified. It has been found also the rare genus Lagenaria (Indo-African origin).

Maize landraces, remnant of wider open field cultivations, are still farmed in small plots with beans and pumpkins. Maize cultivars, widely distributed from valley to mountain sites, are all indurata types with short (40 days) medium (to 90) biological cycle distinct for their kernel colour, from purple, red (the most common in Pollino area) to yellow and white. Tomato is the last introduced important Columbian species, widely distributed and farmed in rural gardens, with maximum richness (5 - 6 different cultivars) per landscape unit in Serrapotamo and Mercure areas. The CWD tomato, used for salads, is Pomettone type. The winter, green-yellow coloured, cherry-type landrace, Invernale a grappolo with at least two biotypes, cultivated in dry soil is RLD and thus under risk of extinction. Reproduced in situ is the old cultivar $S$. marzano which performs well either for salads or sauce.

Among the pre-Columbian crops, bread wheat is represented by Carosella landrace, heterogeneous for the red and white kernel types. Carosella is cultivated at $1000 \mathrm{~m}$ above sea level. Durum wheat is, in several places, represented by the old cultivar Cappelli; here denominated "ancient Cappelli" to mark the authentic ancestry. Barley and hoat were also inventoried as RLD. Cicer arietinum, Vicia faba, Lathyrus sativus and Vicia sativa (traditional open field legume crops) are the remnant of landraces. L. sativus and V. sativa are spontaneously growing on the margin of country paths. Lens esculenta is rare and locally farmed.

Among the garden vegetables, Allium sativus (common garlic), the type with reddish skin is CWD. In opposite, Allium ampeloprasum var Holmense (great headed garlic), the hexaploid type [32] with white skin, is RLD. Allium coepa (onion), represented by the old cultivar Senise, is also well distributed.

Worthy of interest are Brassica rapa and Cichorium indivia latifolium sub-populations. Both types represent the domesticated gene pool growing under minimum tillage condition.

Cynara cardunculus ssp. Scolymus (artichoke), the Roman type, is represented by perennial cultivars bearing a robust woody rhizome. Lactuca sativa cv longifolia (lettuce) and Brassica oleracea "verza or cappuccio" types showed both ancient local ancestry.

Additional important herbs and spices such as Petroselinum crispum, Rosmarinus officinalis, Apium graveolens var. dulce, Origanum vulgare, Salvia officinalis, Foeniculum vulgare, Matricaria camomilla, Ruta graveolens, Sedum telephium, Lavandula angustifolia, Armoracia rusticana and Ocimum basilicum are common in the gardens. O. basilicum is represented by traditional well adapted cultivars producing intense aroma from elliptical leaves.

Locally distributed in Serrapotamo area is Lepidium sativum, probably introduced from Africa, and Coriandrum sativum, which marks the Greek historical tradition.

\subsection{The Realized Niche}

Mercure catchment basin is the core area of the genetic reserve (red area in Figure 4 and Figure 5). Its geomorphology and climate favour maximum species and cultivar richness.

The upper part of Mercure appears as a reversed cone with basal diameter (valley at $250-500 \mathrm{~m}$ a.s.l.) of $\sim 5$ $\mathrm{Km} \times 10 \mathrm{Km}$, and top section diameter (at $\sim 1000 \mathrm{~m}$ ) of $15-20 \mathrm{~km}$ (Figure 1). Warm-humid air from the Tyrrhenian Sea penetrates the valley through the WSW oriented Lao river gorge. Temperate-humid air persists into Mercure area because of the lack of exit channels.

The above described background attributes establish the climatic range of the ecological niche by allowing cultivar farming at different altitudinal layers. The farming delay, from valley to mountain, ranges from one week to one month

The driest month (July) does not coincide with the warmest (August) (Figure 6). Precipitation of the warmest trimester $(100-150 \mathrm{~mm})$ is two times higher than that of the lower Sinni valley $(50-75 \mathrm{~mm}$ ) (Figure 1 and Figure 6); the different level of precipitation is associated to the atmospheric humidity. In September-following the May, June, July and August water deficit—-the equilibrium between vapour transpiration and precipitation is met (Figure 6).

Summer deficits are compensated by locally distributed springs and permanent water sources. The maximum variance for precipitation and temperature recorded in October indicates that this month can be dry (perception 
of the "longer summer") or humid (Table 3, Figure 6). The above climatic pattern favoured the adaptation of Sub-tropical and Columbian cultivars. The favourable environmental range of Mercure area defines the realized niche for plant genetic resources [33].

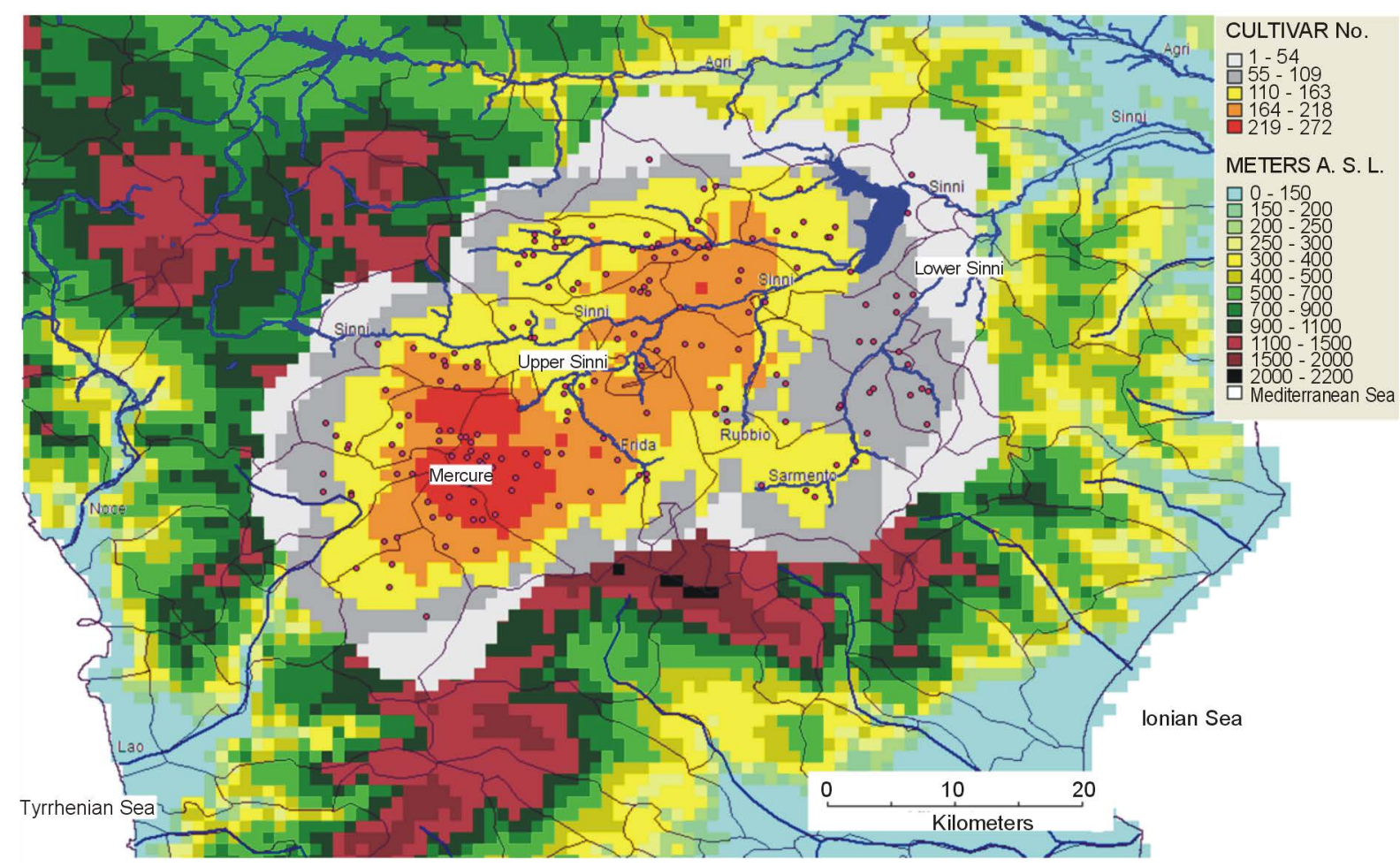

Figure 4. Cultivar richness pattern obtained with the "circular neighborhood" option, adopting a "grid richness analysis" with 30 arc second cell size and circular neighborhood of 0.1 degree including 119 sampling sites $\left({ }^{\circ}\right)$ in an area of $1500 \mathrm{~km}^{2}$.

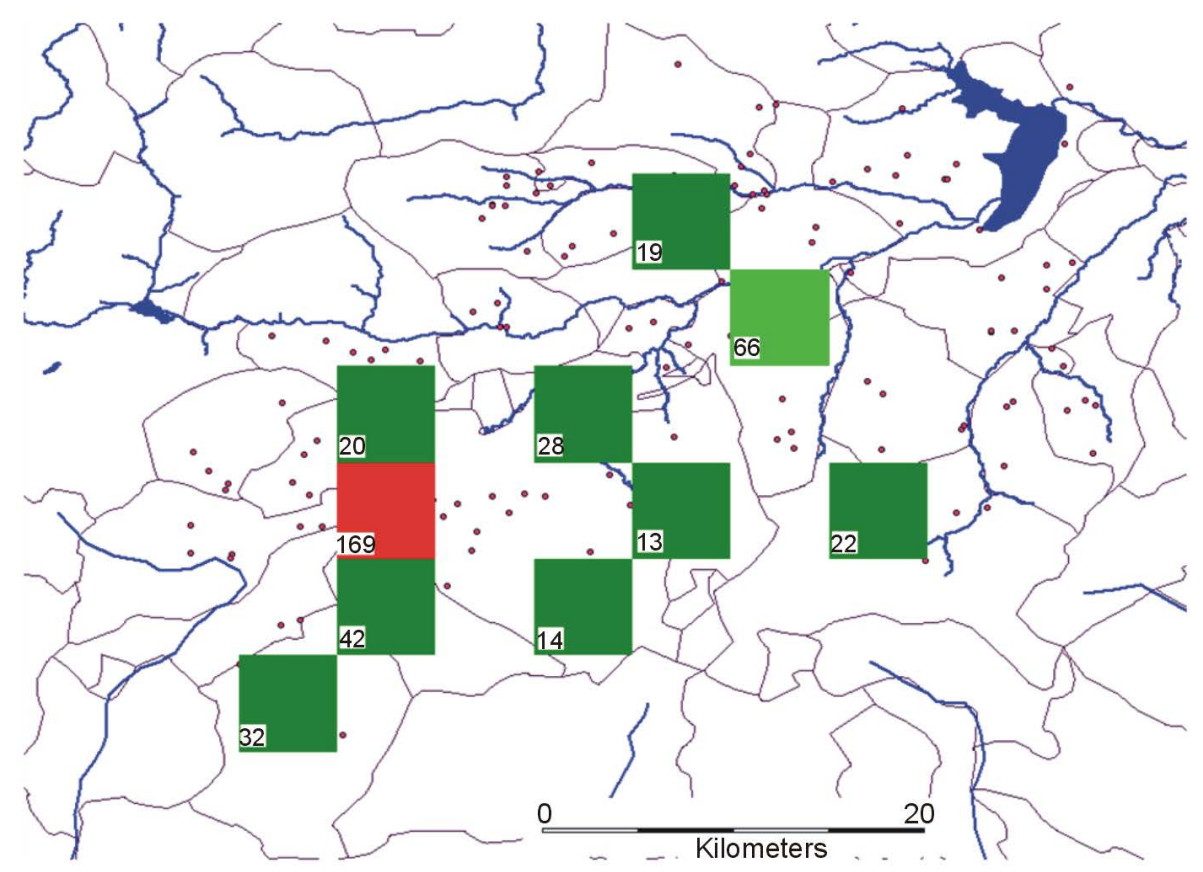

Figure 5. Genetic reserve mapped with the principle of complementarity. Number of distinct cultivars (No. in the left cell side) are absent in all other cells. 

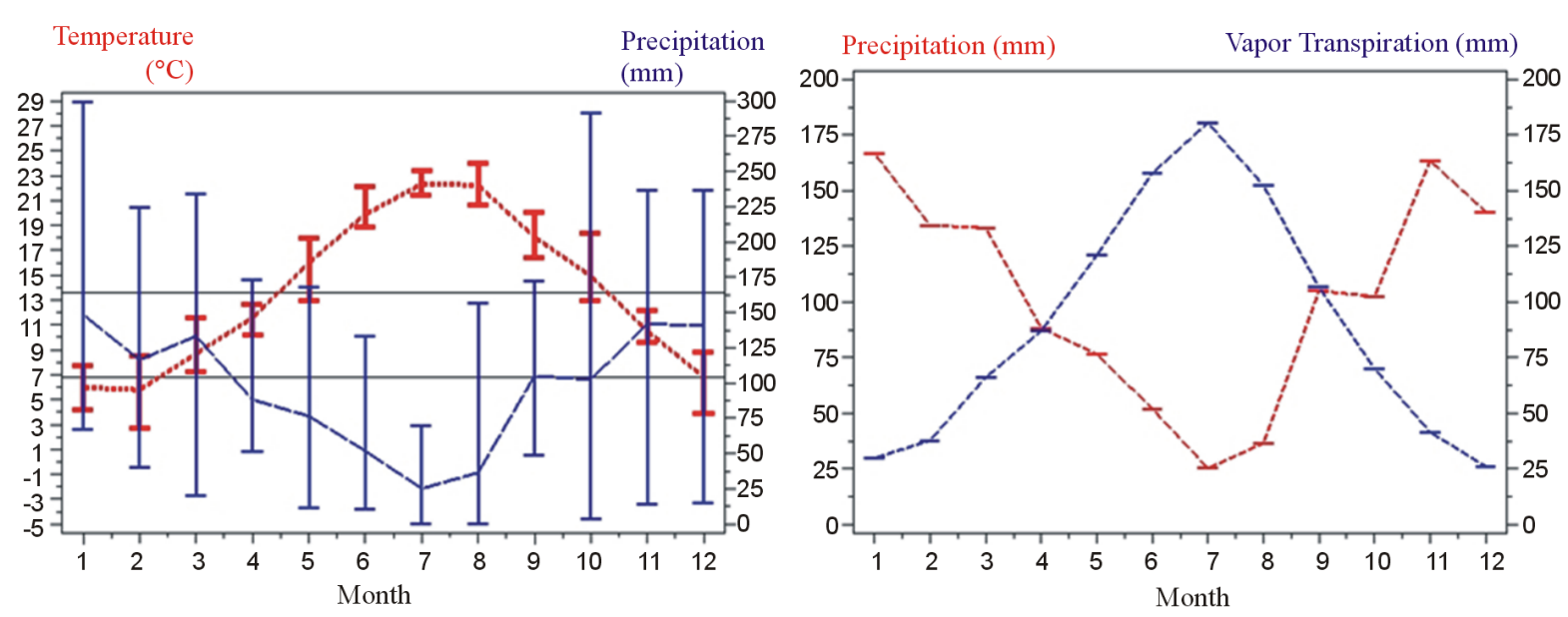

Figure 6. Climatic attributes of Mercure area recorded from 2000 to 2011 at experimental farm site, 540 m a.s.l., exposition NNW.

Table 3. Mercure bioclimatic variables.

\begin{tabular}{cc}
\hline Bioclimatic variable (years: 2000-2011) & Value \\
Average annual temperature & $13.6^{\circ} \mathrm{C}$ \\
Monthly temperature average range & $9.5^{\circ} \mathrm{C}$ \\
Isothermality (2/7) $\times 100$ & $35.4 \%$ \\
Temperature seasonality (std $\times 100)$ & 602 \\
Warmest month (August) maximum temperature & $28.9^{\circ} \mathrm{C}$ (peak $\left.=+39.7^{\circ} \mathrm{C}\right)$ \\
Coldest month (February) minimum temperature & $2.5^{\circ} \mathrm{C}($ peak $=-6.3$ in December) \\
Annual temperature range & $26.8^{\circ} \mathrm{C}$ \\
Wettest (=coldest) trimester (I) average temperature & $6.8^{\circ} \mathrm{C}$ \\
Driest (=warmest) trimester (III) average temperature & $20.9^{\circ} \mathrm{C}$ \\
Annual precipitation & $1224 \mathrm{~mm}$ \\
Wettest month (January) precipitation & $166.6 \mathrm{~mm}$ \\
Driest month (July) precipitation & $25.6 \mathrm{~mm}$ \\
Precipitation seasonality (CV) & 46.7 \\
Wettest (=coldest) trimester (I) precipitation & $434.4 \mathrm{~mm}$ \\
Driest (=warmest) trimester (III) precipitation & $166.7 \mathrm{~mm}$ \\
\hline
\end{tabular}

\section{Discussion}

\subsection{Anthropological Context}

The anthropological variables together with the ecological factors appear to have major influence on the microevolution and distribution of domesticated plants. For Pollino study area, additional studies are needed to assess and validate the relevant role played by the Greek-Byzantine and Albanian influence [19] in shaping the cultivar use, farming, conservation and vernacular names. We recognize the importance of maintaining the underlying anthropological features which support the agro-biodiversity pattern of the study area. Nonetheless, the acknowledgement of the value of the anthropological context needs putting tangible conservation actions into practice. It is relevant to involve, since the first stages of any conservation plan, the local people (citizens, network of rural families and schools) to build local ownership of the biological heritage. The implementation of cyclic (e.g. biodiversity display, meetings, etc.) and ritual best practices (e.g. grafting day) would benefit the in situ conservation over a biological temporal scale. 


\subsection{Diversity Trends}

Gene-pools within the 19th century landraces were genetically heterogeneous. Perceptual traits, at that time, were effective at distinguishing different landraces within a species [21]. At present, the relicts of widespread landraces (e.g. wheat Carosella and maize indurata), the neglected cultivars (e.g. ancient Cappelli and tomatoes), and the rare genotypes adapted to unique agri-ecological contexts (e.g. monumental fruit trees and grape vines) are entities we denominate “ancient cultivars”. Perceptual traits performed well in delineating short cycle ancient cultivars. It would have been unrealistic carrying out agro-biodiversity spatial analysis, at a multi-species level, based upon expert-advised descriptor lists (molecular markers included).

Nonetheless, diversity for fruit trees such as apple, pear and fig, could have been biased because of the long cycle cultivars phenotypic plasticity. In opposite, for cherry, almond, kaki, pomegranate, mulberry, herbs and spices it could be supposed an under-estimate of diversity because of the homogeneity of their perceptual traits.

Overall, long cycle ancient species displayed higher cultivar richness than short cycle species. In the Roman age more than 50 different pear types were already known (e.g. Syriaticum, Tiberianum, Milesium, Tarentinum) and several apple cultivars (the most appreciated: malum Matianum and malum Appium) named according to the grafter name or the cultivar geographic origin [34].

The Columbian species, lately, have significantly increased their herbaceous component richness. At the present, the genetic erosion of short cycle forage crops is high. For instance landraces of Vicia sativa, Medicago lupolina, Medicago sativa, Triticum dicoccon have not been found, despite they were widely farmed in the last century. Cultivar richness detected in this study $($ No. $=585)$ is similar to central Italy (No. $=400$ landraces) [35]. In Latium have been scored 128 fruit tree cultivars [36] and, the Apulian richness for ancient grape vines is consistent with our data [37]. Richness diminution since 1800 is true for almost all crops but, fortunately, not true for Vitis [38] [39]. Grape vine cultivar richness in the past two centuries increased: In 1810, about 70 different cultivars have been surveyed in Basilicata region [39]; similar richness has been scored (No. = 71), in this survey, on the Pollino sub-region (6.6 times smaller than Basilicata). Nonetheless, because of the reduced relative abundance of each grape vine cultivar per farm, at the present, the biodiversity index for grape vine cultivars must be lower. The number of bean landraces lately assessed in Pollino area was 19 [38]. Although it was noticed a significant land abandon as consequence of ageing local people, at the present the number of bean cultivars and their phythonimes have not changed.

Describing agro-biodiversity trends requires appropriate indicators. The popular richness index needs to be weighted with specific landscape units (first level grid cell unit, geographic area, region, country etc.) Assessing biodiversity with quantitative indices and appropriate sampling designs would benefit both conservation genetics and conservation policy.

\subsection{Drivers of Genetic Erosion}

Cultivar richness, the outcome of micro-evolution under domestication [40], has been significantly threatened by the processes of agricultural intensification [41] which reduce the agro-ecosystem resilience by inducing continuous use of external inputs [42]. Landraces genetic erosion is very advanced in western countries. After all, the ancient cultivars, relicts from landraces, are still worthy across the basal layer of the Italian Apennine, because of the persistence of small-scale and low input agriculture [35] [36] [38] [43]. The fall of the so-called small-scale integrated crop-livestock production systems (rabbits, pigeons, hens, pigs, donkeys, pigs and horses) has promoted the abandon of the autumn-winter, winter-spring herbages along with open field seed-producing crops. Labor-related factors are also additional drivers of the genetic erosion especially for Pisum sativum, Vicia faba var minima and media, Avena sativa, Cicer arietinum and Lens esculenta. On the contrary, in situ conservation of garden vegetables and fruit tree species is more efficient because of their easy regeneration in small sized-parcels for self-consumption.

The following biological (point 1 - 6) and socio-economic (point 7 and 8) properties are exhibited by the most efficiently in situ conserved cultivars:

1) Long life cycle, associated to vegetative propagation, ensures minimum vulnerability (e.g. fruit trees, grape vines, perennial herbs).

2) Monoecy, with prevalent self-fertilization, allows the genetic identity of each cultivar by storing few seeds, generation after generation (e.g. bean, pepper, tomato and eggplant). 
3) Sufficient effective population size ( $\mathrm{Ne})$ is easily maintained for some cross-pollinated species. Maize is maintained, year after year, by storing few cobs. Seed exchange and wind pollination will maintain the required levels of heterozygosis. Nonetheless, pollen flow from hybrid indentata cultivars impairs the genetic integrity of ancient indurata maize.

4) Inbreeding tolerance of the insect-pollinated pumpkin cultivars contributes for their adaptation. Nonetheless, population size reduction limits plant fertility (e.g. cucurbitaceae).

5) Adaptation to minimum tillage takes place. Brassica rapa, Cichorium indivia latifolium and Coriandrum sativum are self-reproducing populations under minimum tillage conditions. Nonetheless, minimum population size and land abandonment are limiting factors for their in situ conservation.

6) Escape from virus infections in mountain sites where the ancient cultivars of potatoes are cultivated. Red skin bulbs appear more resistant to soil borne diseases (e. g. garlic and onion).

7) Competition of the ancient cultivars vs. homologous trading goods. The improved use of certified traditional cultivars through appropriate marketing strategies has favored their exit from the extinction risk (e.g. white bean and red eggplant of Rotonda, red capsicum of Senise).

8) Awareness about the local ownership of the biological heritage.

\subsection{Agro-Biodiversity Model}

"Several cultivars vs. few hectares” rather than "one cultivar vs. several hectares” is the paradigm for landscapes molecularly managed by small-holder farmers. Shifting from the poly-production to specialization, the above peripheral landscapes would undergo to dramatic genetic erosion. The model in Figure 7 includes as source of variation cultivar richness, species richness and niche diversity. From the array of cases depicted in Figure 7 it results that the worst case (low diversity) in traditional agriculture matches with the best case (high diversity) in specialized agriculture.

Agro-biodiversity distribution in Pollino National Park is consistent with the existence of agro-ecosystem units keeping both species richness and cultivar richness, under niche diversity conditions. The hypothesis of an alternative model based on several differentiated and specialized agro-ecosystem units has not been confirmed. It follows that rural developmental plans aimed at biodiversity conservation would benefit from the use of appropriate diversity indices rather than by accounting for sizes in hectares farmed with the so-called "autochthonous" cultivars.
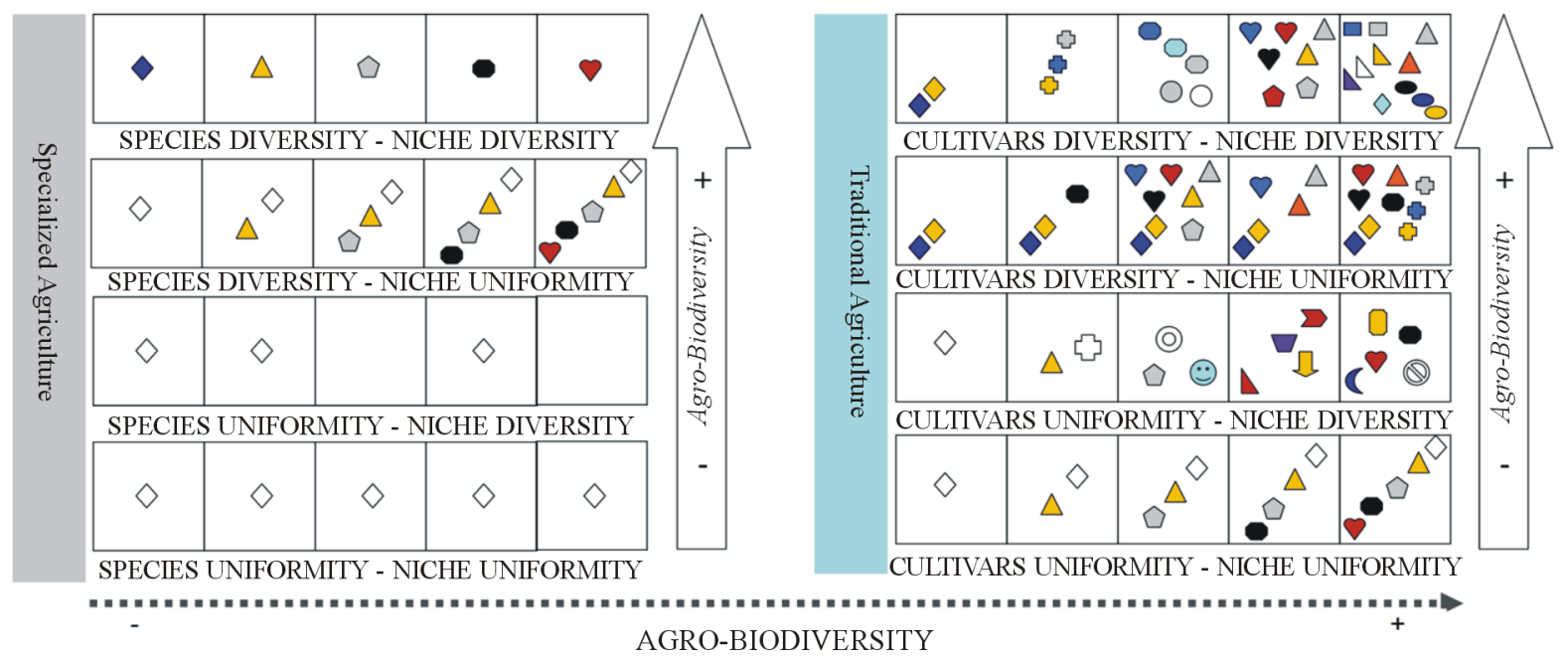

AGRO-BIODIVERSITY

Figure 7. Maximum parsimony agro-biodiversity pattern model hypothesized for specialized (left) and traditional agriculture (right). Each square is a landscape unit; different symbols refer to different species; different colours/symbol refer to different cultivars. Basic assumption for specialized agriculture is cultivar uniformity (variable species No. is allowed) within a variable niche context. Basic assumption for traditional agriculture is species diversity (variable cultivars No. within species is allowed) within a variable niche context. Species absence within a landscape unit indicates lack of cultivar adaptation (empty niche). At least one cultivar is adapted to different landscape units in case of niche uniformity. 


\subsection{Responses}

In situ conservation is not a steady state. Conservation must be dynamic as the populations evolve and adapt to external pressures. For each ancient cultivar the progress of micro-evolution must be ensured by enhancing seed exchange, pollination (migration) and population size increase (which reduces genetic drift) at site level. Perceptual traits should be sufficient to maintain cultivar authenticity and distinction.

Nevertheless, the concepts of genetic uniformity and stability, adopted by the market rules, could be misleading to the objectives of dynamic conservation. Conventional agricultural policies are often ineffective to conserve species, cultivars and biotypes at risk of extinction in landscapes with high natural heritage. The bureaucratic burden required by the European conservation policy does not appear proportional to either the generally small land sizes or to the custodians' profiles often not recognized as farmers. Thus any action—scientific, religious, managerial, ethnic, business driven — aimed at maintaining cultivar diversity should be promoted. In the circumstance of budget shortages limiting widely distributed responses, the Genetic Reserve, as key sub-area, can replace the whole landscape. The Genetic Reserve represents a parsimonious tool, not yet implemented into the agricultural policies, for putting into practice the so called active and long-term dynamic in situ conservation.

Practices from the tradition can suggest appropriate conservation actions. For example the shepherds since long time have been practicing the graft of the best pear and apple biotypes on wild or semi-wild plants at the margin of the flock path. This tradition suggested us the conservation method we defined "conservation in semi-natural environment” practiced in the saltus areas of Pollino National Park [44]. The conservation in semi-natural environment is linked to the grafting day which involves people in shone exchange and grafting.

On the other hand, management guidelines taking into account either the breeding system or the biological cycle are needed for different genetic categories. Cultural and ethnic drivers linked to genetic diversity need a deeper understanding [45]. Merging landscape ecology, genetics and anthropology would attempt to highlight important links between local culture, linguistic diversity and agro-biodiversity.

\section{Conclusion}

The intrinsic value of the unique landscape depicted in this paper, as consequence of converging pressures from inappropriate projects and rural policy inertia, is declining. Thus, a scientifically sound management plan for agro-biodiversity, covering the medium-long term time scale, would be profitable for the Pollino National Park.

\section{Acknowledgements}

Data analysis and manuscript design followed the agreement between Pollino National Park and Dept. of the Mediterranean Cultures (DICEM) for the identification of the in situ genetic reserve of plant genetic resources.

\section{References}

[1] Guarino, L., Jarvis, A., Hijimans, R.J. and Maxted, N. (2002) Geographic Information Systems (GIS) and the Conservation and Use of Plant Genetic Resources. In: Engels, J.M.M., Ramanatha Rao, V., Brown, A.H.D. and Jackson, M.T. Eds., Managing Plant Genetic Diversity, International Plant Genetic Resources Institute, Rome, 387-404.

[2] Scheldeman, X. and van Zonneveld, M. (2010) Training Manual on Spatial Analysis of Plant Diversity and Distribution. Bioversity International, Rome, 1-179. http://www.bioversityinternational.org/index.php?id=19\&user_bioversitypublications_pi1[showUid]=5052

[3] Brush, S.B. (1991) A Farmer Based-Approach to Conserving Crop Germplasm. Economic Botany, 45, 153-165. http://dx.doi.org/10.1007/BF02862044

[4] Figliuolo, G. (2010) Ogm e Paesaggio: Il Contesto Europeo. Biologi Italiani, 7, 56-64.

[5] Bianco, P., Forconi, V., Lazzerini, C., Mandrone, S., Vazzana, C. and Vicini, C. (2010) Agricultural Areas with High Natural Value: Identification and Management. Istituto Superiore Protezione and Ricerca Ambientale, Book and Guideline, Rome.

[6] UNCED (1992) Biodiversity Convention. United Nations Conference on Environment and Development, Geneva.

[7] FAO (2009) The International Treaty on Plant Genetic Resources for Food and Agriculture. Food and Agriculture Organization of the United Nations, Rome.

[8] Commission Directive EC (2008) Providing for Certain Derogations for Acceptance of Agricultural Landraces and Va- 
rieties Which Are Naturally Adapted to the Local and Regional Conditions and Threatened by Genetic Erosion and for Marketing of Seed and Seed Potatoes of Those Landraces and Varieties. Official Journal of the Europe, L162, 13-19.

[9] Council Regulation EC (2005) On Support for Rural Development by the European Agricultural Fund for Rural Development (EAFRD). Official Journal of the Europe, L277, 1-37.

[10] Altieri, M.A. and Merrick, L.C. (1987) In Situ Conservation of Crop Genetic Resources through Maintenance of Traditional Farming Systems. Economic Botany, 41, 86-96. http://dx.doi.org/10.1007/BF02859354

[11] Oldfield, M.L. and Alcorn, J.B. (1987) Conservation of Traditional Agro-Ecosystems. Bioscience, 37, $199-208$. http://dx.doi.org/10.2307/1310519

[12] Figliuolo, G. (2006) Protocollo 1: Frammentazione del Paesaggio e Variazioni del Contesto Ambientale. Monitoraggio Della Flora Domesticata. The AgriBioDiversity (ABD) Project: Development of a Monitoring Programme for the Val D’Agri, Università Degli Studi Della Basilicata, Potenza, 1-94.

[13] OECD (1997) OECD Environmental Performance Reviews: A Practical Approach. Organization for Economic CoOperation and Development, Paris, 1-90.

[14] Bevilacqua, P. (1996) Habitat ed Economia Degli Alberi in Sud Italia. In: Donizelli, Ed., Tra Natura e Storia, Ambiente, Economie, Risorse in Italia, Rome.

[15] Compagnucci, F. and Mazzoni, F. (2002) Il Territorio dei Parchi Nazionali Italiani. Quaderni di Ricerca, No. 172, Università degli Studi di Ancona Dipartimento di Economia, Ancona.

[16] Cantore, V., Iovino, F. and Pontecorvo, G. (1987) Climatic Traits and Phitoclimatic Belts of Basilicata. National Research Council, Istituto di Ecologia e Idrologia Forestale, No. 2, 3-49.

[17] Sereni, E. (1961) Storia del Paesaggio Agrario. Laterza, Bari, 1-499.

[18] Figliuolo, G., Cerbino, D., Gallo, S., et al. (2010) Gli Antichi Fruttiferi del Pollino. Quaderni Alsia, Agenzia Lucana Sviluppo and Innovazione in Agricoltura, Year X, Matera, 1-110. http://www.biodiversitapollino.it/export/test/documenti/quaderni alsia.pdf

[19] Racioppi, G. (1889) Storia dei popoli di Lucania e Basilicata. Vol. 1, Vol. 2, Loescher \& C., Rome.

[20] Cavalli Sforza, L.L., Menozzi, P. and Piazza, A. (1994) History and Geography of Human Genes. Princeton University Press, Princeton.

[21] Gibson, R.W. (2009) A Review of Perceptual Distinctiveness in Landraces Including an Analysis of How Its Roles Have Been Overlooked in Plant Breeding for Low Input Farming System. Economic Botany, 63, 242-255. http://dx.doi.org/10.1007/s12231-009-9086-3

[22] Favia, M. (2013) Project Metacultura: General Topics of the Biodiversity Research. Report. http://www.basilicatanet.com/ita/web/nav.asp?nav=biodiversitamontagnamaterana

[23] Eni (2005) The AgriBioDiversity (ABD) Project: Development of a Monitoring Programme for the Val D’Agri. Report, Eni S.p.A, Exploration \& Production Division, Doc. No. 0034, AMTE, Milan, 1-44.

[24] Cerbino, D., Zienna, P., Illiano, M., et al. (2012) Antiche varietà cerealicole ed orticole del Pollino. Quaderni Alsia, Agenzia Lucana Sviluppo and Innovazione in Agricoltura, Year XII, Matera, 1-112.

[25] Hijmans, R.J., Guarino, L., Jarvis, A., O’Brien, R., Mathur, P., Bussink, C., Cruz, M., Barrantes, I. and Rojas, E. (2005) Diva-Gis Manual. 1-73. http://www.diva-gis.org

[26] Rebelo, A.G. and Sigfred, W.R. (1992) Where Should Nature Reserves Be Located in the Cape Floristic Region, South Africa? Models for Spatial Configuration of a Reserve Network Aimed at Maximizing the Protection of Diversity. Conservation Biology, 6, 243-252. http://dx.doi.org/10.1046/j.1523-1739.1992.620243.x

[27] Brown, A.H.D. (2008) Indicators of Genetic Diversity, Genetic Erosion and Genetic Vulnerability for Plant Genetic Resources for Food and Agriculture. Bioversity International, Rome, 1-26. http://www.fao.org/docrep/013/i1500e/i1500e20.pdf

[28] Pavari, A. (1916) Valutazione preliminare della coltivazione di specie forestali esotiche in Italia. General Section, Annales of the Regio Istituto Superiore Forestale Nazionale, Florence, 1-221.

[29] Basilicata, R. (2003) Mappa Pedologica della Basilicata Region. Workshop on Pedologic Survey to Know, Safeguard and Valorise Basilicata Landscape and Agriculture, Basilicata Region, Department Agriculture and Rural Development, 7 April 2003, 1-54.

[30] Busby, J.R. (1991) Bioclim, a Bioclimatic Analysis and Prediction System. In: Margules, C.R. and Austin, M.P., Eds., Nature Conservation: Cost Effective Biological Surveys and Data Analysis, CSIRO, Canberra, 64-68.

[31] Sas (2013) Statistical Analysis Software ver. 9.1. North Cary. http://www.sas.com

[32] Guenaoui, C., Mand, S., Figliuolo, G. and Neffati, M. (2013) Diversity in Allium ampeloprasum: From Small and Wild to Large and Cultivated. Genetic Resources and Crop Evolution, 60, 97-114. 
http://dx.doi.org/10.1007/s10722-012-9819-5

[33] Puliam, H.R. (2000) On the Relationship between Niche and Distribution. Ecology Letters, 3, 349-361. http://dx.doi.org/10.1046/j.1461-0248.2000.00143.x

[34] Nava, M.L., Osanna, M. and De Faveri, C. (2007) Antica Flora Della Lucania: Historical and Archeological Inventory. Soprintendenza Beni Archeologici of Basilicata, Osanna, Venosa.

[35] Negri, V. (2003) Landraces in Central Italy: Where and Why They Are Conserved and Perspectives for Their On-Farm Conservation. Genetic Resources and Crop Evolution, 50, 871-885. http://dx.doi.org/10.1023/A:1025933613279

[36] Pavia, R., Barbagiovanni, I., Della Strada, G., Piazza, M.G., Engel, P. and Fideghelli, C. (2007) Autochthonous Fruit Tree Germplasm at Risk of Genetic Erosion Found in Home Gardens in the Region of Latium (Italy). Proceedings of the Workshop on Crop Genetic Resources in European Home Gardens, Bioversity International, Ljubljana, 3-4 October 2007, 21-25.

[37] Antonacci, D. (2004) Vitigni della Puglia. Regione Puglia and Istituto Sperimentale Vinicoltura.

[38] Masi, P., Figliuolo, G. and Zeuli, P.L.S. (1999) Landraces of Bean (Phaseolus vulgaris L.) Collected in Basilicata, Italy. FAO/IPGRI Plant Genetic Resources Newsletter, 119, 51-55.

[39] Verrastro, V., Carbone, E. and Figliuolo, G. (2007) Ricchezza di specie di importanza economica nella Basilicata del XIX secolo. Biologi Italiani, No. 9, 62-69.

[40] Harlan, J.R. (1975) Crops \& Man. 2nd Edition, American Society of Agronomy, Crop Science Society of America, Inc., Madison.

[41] FAO (2010) The Second Report on the State of the World's Plant Genetic Resources for Food and Agriculture. Food and Agriculture Organization of the United Nations, Rome.

[42] FAO-PAR (2011) Biodiversity for Food and Agriculture. Food and Agriculture Organization of the United Nations and the Platform for Agrobiodiversity Research, Rome.

[43] Piergiovanni, A.R., Brandi, M., Cerbino, D., Olita, G., Perrino, P. and Laghetti, G. (2001) Common Bean AgroEcotypes (Phaseolus vulgaris L.) of Sarconi and Rotonda (Basilicata, Italy). Agrifoglio, No. 15, Quaderno No. 2.

[44] Figliuolo, G. and Cerbino, D. (2011) Il giardino dell'Eden è sul Pollino. Agrifoglio, 40, 13.

[45] Pretty, J., Adams, B., Berkes, F., Ferreira de Athayde, S., Dudley, N., Hunn, E., Maffi, L., Milton, K., Rapport, D., Robbins, P., Sterling, E., Stolton, S., Tsing, A., Vintinner, E. and Pilgrim, S. (2010) The Intersections of Biological Diversity and Cultural Diversity: Towards Integration. Conservation and Society, 7, 100-112. 